Peter J. Grund and Erik Smitterberg. 2014 "Conjuncts in Nineteenth-Century English: Diachronic Development and Genre Diversity." English Language and Linguistics 18(1): 157-181. (Accepted manuscript version; post-peer review)

Conjuncts in nineteenth-century English: Diachronic development and genre diversity

PETER J. GRUND and ERIK SMITTERBERG

Contact information:

Dr. Peter J. Grund

Department of English

Wescoe Hall Rm. 3001

University of Kansas

1445 Jayhawk Blvd.

Lawrence, KS 66045

USA

pjgrund@ku.edu

Dr. Erik Smitterberg

Department of English

Uppsala University

P.O. Box 527

SE-751 20 UPPSALA

Sweden

erik.smitterberg@engelska.uu.se 
Peter J. Grund and Erik Smitterberg. 2014 "Conjuncts in Nineteenth-Century English: Diachronic Development and Genre Diversity." English Language and Linguistics 18(1): 157-181. (Accepted manuscript version; post-peer review)

Conjuncts in nineteenth-century English: Diachronic development and genre diversity

PETER J. GRUND and ERIK SMITTERBERG

University of Kansas and Uppsala University 
Peter J. Grund and Erik Smitterberg. 2014 "Conjuncts in Nineteenth-Century English: Diachronic Development and Genre Diversity." English Language and Linguistics 18(1): 157-181. (Accepted manuscript version; post-peer review)

Abstract

This article explores the use of connective adverbials or CONJUNCTS (e.g. therefore, on the other hand, firstly) in nineteenth-century English. Drawing on A Corpus of Nineteenth-Century English (CONCE), the study focuses on charting change over time and variation among different genres, and considers the distribution of various semantic types (e.g. contrastive, resultive) as well as individual conjuncts and author styles. We show that nineteenth-century English displays considerable genre differentiation in the use of conjuncts, both in terms of frequency and semantic types of conjuncts employed. Within these larger trends, patterns are also evident for individual conjuncts (e.g. now, therefore, so) and individual authors (e.g. in Letters). Science writing, in particular, reveals a drastic increase in conjuncts (in nearly all semantic types), which sets it apart from other genres. This suggests that the conjunct-heavy style of academic writing that has been attested in studies of Present-Day English was established in the nineteenth century. On a more general level, this result underlines the importance of considering formal genres when charting language change, as they may be in the forefront of the formation of new linguistic patterns that are unique to written texts. The article also contributes to our growing understanding of Late Modern English syntax. 
Peter J. Grund and Erik Smitterberg. 2014 "Conjuncts in Nineteenth-Century English: Diachronic Development and Genre Diversity.” English Language and Linguistics 18(1): 157-181. (Accepted manuscript version; post-peer review)

1 INTRODUCTION

Speakers of English have a number of options at their disposal for marking how they view the connection between two linguistic units (whether words, phrases, clauses, sentences, or even larger units). Prominent among these resources are CONJUNCTS, in the terminology of Quirk et al. (1985: 631-47), also known as LINKING ADVERBIALS (Biber et al. 1999: 875), ADVERBIAL CONNECTORS (Lenker 2010; 2011), and CONNECTIVE ADJUNCTS (Mittwoch, Huddleston \& Collins 2002: 775). Such adverbials usually appear in the shape of adverbs (e.g. therefore, however) and prepositional phrases (e.g. on the other hand, in the first place), and they signal a range of semantic relations including result, addition, and contrast. An example in context is provided in (1), where moreover marks the statement as providing an additional (and perhaps stressed) point in the list of perceived qualities of the 'Mahratta'.

(1) Joining their sports, sharing their hospitality, mingling with them in the smoking-room and at the billiard-table, this Mahratta had won the confidence of British officers. He was a man, moreover, in whom it seemed generous to confide.

(History, Walpole, 1870-1900, p. VI.305)

A number of studies have been devoted to the use of conjuncts because of their importance as organizational features in English writing and speech. However, while research into the present-day situation has outlined the inventory and parameters of 
Peter J. Grund and Erik Smitterberg. 2014 "Conjuncts in Nineteenth-Century English: Diachronic Development and Genre Diversity." English Language and Linguistics 18(1): 157-181. (Accepted manuscript version; post-peer review)

usage in some detail, the historical development of conjuncts has only recently received systematic attention.

The aim of our article is to contribute to this historical picture by exploring the use of conjuncts in nineteenth-century British English, based on data from A Corpus of Nineteenth-Century English (CONCE). We are particularly concerned with charting their frequency over the century and across different genres and semantic categories, but we also pay attention to the distribution of individual conjuncts and to author-specific styles. The impetus for our study comes from Lenker's (2010) monograph on connectives in English. Lenker (2010: 9) singles out Late Modern English as a period of special interest in terms of changes in the conjunctive system. Our study expands on Lenker's (2010) findings by investigating the more fine-grained development of conjuncts within the Late Modern English period, and by considering in particular what influence the genre parameter, which has been shown to have a substantial impact on present-day patterns, may have had historically. More generally, our study contributes to the description of Late Modern English syntax, an area of increasing scholarly interest (see Kytö et al. 2006; Tieken-Boon van Ostade \& van der Wurff 2009; Hickey 2010).

\section{PREVIOUS RESEARCH}

Conjuncts have received considerable attention in previous research, from a number of different perspectives, including primarily quantitative, descriptive approaches (e.g. Altenberg 1984, 1986; Markus 2000; Rissanen 2004; Lenker 2010; Meurman-Solin 2011); second/foreign language investigations or approaches to learner vs. professional 
Peter J. Grund and Erik Smitterberg. 2014 "Conjuncts in Nineteenth-Century English: Diachronic Development and Genre Diversity." English Language and Linguistics 18(1): 157-181. (Accepted manuscript version; post-peer review)

writer proficiency (e.g. Gardezi \& Nesi 2009; Shaw 2009; Yeung 2009); and more discourse-analytical, pragmatic studies (e.g. Williams 1996; Barth-Weingarten \& Couper-Kuhlen 2002; Bell 2004, 2010; Haselow 2011, 2012). A major distinction can be made between studies that provide a comprehensive treatment of conjuncts as a group and investigations that deal with a subgroup of conjuncts or individual items. Studies that belong to the former category are relatively few, covering the major descriptive grammars of English (Quirk et al. 1985; Biber et al. 1999; Huddleston \& Pullum 2002) and a few monographs or article-length studies that deal with conjuncts exclusively or as part of a broader framework (e.g. Greenbaum 1969; Halliday \& Hasan 1976; Warner 1985; Ungerer 1988; Lindquist 1989; Halliday 1994; Altenberg 1999; Hyland 2005; Lenker 2010). The latter category, on the other hand, attests to the substantial interest in different semantic categories of conjuncts, including expressions of concession or contrast such as however, nevertheless, and on the other hand (e.g. Borkin 1979, 1980; Altenberg 1986; Barth-Weingarten \& Couper-Kuhlen 2002; Bell 2004, 2010); cause, inference, or result markers such as therefore, thus, and then (e.g. Altenberg 1984; Vandepitte 1993; Markus 2000; Haselow 2011, 2012); and transition signals such as now (e.g. Defour 2008).

Variation is evident among conjuncts in terms of their frequency and their occurrence in a variety of genres, as has been shown in a number of investigations (e.g. Greenbaum 1969; Altenberg 1984, 1986, 1999; Morrow 1989; Biber et al. 1999; Markus 2000; Bell 2004, 2010; Peterson 2009; Yeung 2009; Lenker 2010). A consensus finding of earlier studies is that conjuncts are as a rule more common in academic, informative, learned or formal written genres than in more informal, less specialized writing (see esp. Greenbaum 1969: 80; Altenberg 1984: 39-45; Morrow 1989; Biber et 
Peter J. Grund and Erik Smitterberg. 2014 "Conjuncts in Nineteenth-Century English: Diachronic Development and Genre Diversity." English Language and Linguistics 18(1): 157-181. (Accepted manuscript version; post-peer review)

al. 1999: 880). A prominent division has also been observed between expository or argumentative texts and narrative texts, such as novels and news texts, conjuncts being relatively rare in narratives (Greenbaum 1969: 80; Biber et al. 1999: 880).

Another notable finding in previous research is that conversation reveals conjunct frequencies that rival those of learned, informative written texts (Greenbaum 1969: 80; Biber et al. 1999: 880). The difference between the two domains of usage lies primarily in the specific conjuncts used: then, now, so, anyway, and though, for example, tend to be much more common in speech than in writing, while others such as however, thus, therefore, and for example are characteristic of written language (Altenberg 1984: 40-1; 1986: 16; Biber et al. 1999: 887).

Historical studies of conjuncts are relatively few, and they mostly treat individual conjuncts or subgroups rather than the system of conjuncts (e.g. Finell 1992; Markus 2000; Dorgeloh 2004; Rissanen 2004; Defour 2008; Lenker 2011; MeurmanSolin 2011; Haselow 2012). The only comprehensive historical treatment of conjuncts to date is Lenker's (2010) monograph, which traces the development of conjuncts from Old English up to the present day. Among many revelatory findings, Lenker (2010: 9, 238-41) emphasizes the Late Modern English period as crucial regarding the formation of individual conjuncts, changes in sentence position, and the development of the system of conjuncts. Our results indicate that the nineteenth century was indeed a watershed in the development of, among other things, the conjunct-heavy style that characterizes present-day academic writing.

\section{MATERIAL AND DATA}


Peter J. Grund and Erik Smitterberg. 2014 "Conjuncts in Nineteenth-Century English: Diachronic Development and Genre Diversity.” English Language and Linguistics 18(1): 157-181. (Accepted manuscript version; post-peer review)

\subsection{Material}

The present study is based on CONCE, a one-million-word corpus of British English (for further details, including information on texts included in each period/genre sample, see Smitterberg 2005; Kytö, Rydén \& Smitterberg 2006). The texts in CONCE are stratified into three period samples, thus enabling diachronic analyses: 1800-30 (period 1), 1850-70 (period 2), and 1870-1900 (period 3). As the manual scrutiny required to identify and analyse conjuncts reliably is time-consuming (see section 3.2.2), it was necessary to limit the scope of the study to a subset of CONCE in order to allow us to carry out in-depth analyses of the data. By including periods 1 and 3 only, we could study the full range of genre variation in the corpus while still being able to chart change in the use of conjuncts over the course of the nineteenth century based on quantitatively robust data.

CONCE includes seven genres: Debates, Drama, Fiction, History, Letters, Science, and Trials. The genres are described briefly in table 1.

Table 1. Description of the genres in CONCE (based on Kytö, Rudanko \& Smitterberg

2000: 88)

\begin{tabular}{|l|l|}
\hline Genre & Characteristics \\
\hline Debates & Recorded debates from the Houses of Parliament \\
\hline Drama & Prose comedies or farces \\
\hline Fiction & Novels \\
\hline History & Historical monographs \\
\hline Letters & Private, personal letters between relatives or close friends \\
\hline Science & Monographs pertaining to the natural or social sciences \\
\hline Trials & Recorded trial proceedings (chiefly in dialogue format) \\
\hline
\end{tabular}


Peter J. Grund and Erik Smitterberg. 2014 "Conjuncts in Nineteenth-Century English: Diachronic Development and Genre Diversity." English Language and Linguistics 18(1): 157-181. (Accepted manuscript version; post-peer review)

Besides including both narrative and non-narrative language, CONCE covers informal genres like Letters as well as formal, literate genres such as History and Science. In addition, formal speech written down (Debates and Trials) and informal, constructed speech (Drama, dialogue in Fiction) are both represented in the corpus. The genre setup of CONCE thus provides a good opportunity to study possible variation across a number of genres, and to see whether some of the genre characteristics reported by Greenbaum (1969: 80) and Biber et al. (1999) for twentieth-century English are present in the nineteenth century as well. Word counts for the period, genre, and period/genre samples included are given in table 2 .

Table 2. Word counts by period and genre in CONCE (periods 1 and 3)

\begin{tabular}{|l|l|l|l|l|l|l|l|l|}
\hline Period & Debates & Drama & Fiction & History & Letters & Science & Trials & Total \\
\hline 1 & 19,908 & 31,311 & 42,032 & 30,904 & 121,624 & 38,037 & 62,360 & 346,176 \\
\hline 3 & 19,947 & 29,090 & 30,113 & 30,564 & 90,891 & 30,603 & 67,588 & 298,796 \\
\hline Total & 39,855 & 60,401 & 72,145 & 61,468 & 212,515 & 68,640 & 129,948 & 644,972 \\
\hline
\end{tabular}

The limited number of source texts used for CONCE (for most genres, three texts per period/genre sample) means that characteristics of individual texts may influence the quantitative picture. This potential limitation notwithstanding, CONCE has been shown to provide reliable evidence of genre variation and development in previous research (e.g. Geisler 2002; Kytö, Rydén \& Smitterberg 2006; Smitterberg 2005, 2012). Moreover, given that identifying and classifying conjuncts requires a great deal of manual work, using a larger corpus was not feasible, and the care that has gone into the selection and transcription of source texts for CONCE outweighs any sampling-related drawbacks. 
Peter J. Grund and Erik Smitterberg. 2014 "Conjuncts in Nineteenth-Century English: Diachronic Development and Genre Diversity.” English Language and Linguistics 18(1): 157-181. (Accepted manuscript version; post-peer review)

\subsection{Data}

\subsubsection{Conjuncts versus other adverbials, other connectors, and discourse markers}

The adverbials that we refer to as conjuncts have been defined in a number of different, though related ways in previous research (see e.g. Greenbaum 1969; Altenberg 1984:

24; 1999: 251; Quirk et al. 1985; Biber et al. 1999; Markus 2000: 216-7; Mittwoch, Huddleston \& Collins 2002: 775-7; Yeung 2009: 330; Hasselgård 2010: 19-23, 301-2;

Lenker 2010: 23-8). In the present study, we rely chiefly on the criteria for conjunct status presented in Quirk et al. (1985). We define conjuncts as non-adjunctive adverbials whose main function is to express the relationship between two linguistic units (or, in some cases, between a linguistic unit and the extralinguistic context - see e.g. Quirk et al. 1985: 633). We use the syntactic tests outlined in Quirk et al. (1985: 504-5, 921-8) to distinguish conjuncts from other structures with a potentially connective function, such as conjunctions and certain adjuncts; for instance, an adjunct can be the focus of a cleft sentence, while other adverbials cannot (Quirk et al. 1985: 504; for the use of a combination of syntactic and semantic criteria, see also Hasselgård 2010: 302). ${ }^{1}$

\footnotetext{
${ }^{1}$ One unavoidable consequence of applying tests of the kind provided in Quirk et al. (1985) to historical material is that a certain degree of anachronism potentially becomes a part of the selection of data (cf. Lenker 2010: 23). However, categories established on the basis of Present-Day English evidence are involved in virtually all historical studies to some extent (cf. Denison \& Hundt 2013), and given the relative similarity to Present-Day English that nineteenth-century English displays, the potential drawbacks of using a framework developed for Present-Day English are offset by the high degree of replicability and precision that such a method allows.
} 
Peter J. Grund and Erik Smitterberg. 2014 "Conjuncts in Nineteenth-Century English: Diachronic Development and Genre Diversity." English Language and Linguistics 18(1): 157-181. (Accepted manuscript version; post-peer review)

It is also important to consider how conjuncts relate to DISCOURSE MARKERS since, depending on which definition of discourse markers we adopt among those that have been proposed, all, some, or none of our conjuncts would appear to qualify as discourse markers (for the wide range of definitions, see Schiffrin 1987; Brinton 1996: 29-38; Jucker \& Ziv 1998: 1-4; Lenk 1998: 49-52; Fraser 1999; Aijmer 2002: 6-7). We chose to follow Biber et al. (1999: 1086-8), who see discourse markers as a separate category from adverbials, including conjuncts, although they admit that differentiating between them is not always easy (see e.g. Biber et al. 1999: 880, 889, 1086). They emphasize the conversational and interactive nature of discourse markers. In their discussion of so, they also suggest that discourse markers have little or no semantic content (Biber et al. 1999: 878). For our purposes, the distinction between conjunctive and discourse-marker functions proved particularly useful in the treatment of $s o$, as in (2).

(2) By way of a coarse analogy, consider a parallel-sided piece of glass through which light passes. It forms no picture. Shape it so as to be bi-convex, and a picture appears in its focus.

Is not the formation of the picture a "function" of the piece of glass thus shaped?

So, from your own point of view, suppose a mind-stuff - $\lambda$ ó $\gamma \circ \varsigma-\mathrm{a}$ noumenal cosmic light such as is shadowed in the fourth gospel. The brain of a dog will convert it into one set of phenomenal pictures, and the brain of a man into another. But in both cases the result is the consequence of the way in which the respective brains perform their "functions." 
Peter J. Grund and Erik Smitterberg. 2014 "Conjuncts in Nineteenth-Century English: Diachronic Development and Genre Diversity." English Language and Linguistics 18(1): 157-181. (Accepted manuscript version; post-peer review)

(Letters, Huxley, 1870-1900, p. 299)

In (2), the main function of so seems to be to mark the return to the main strand of the author's argument after the intervening yes/no question (a conversational function). This example appears to fit similar uses of so as a discourse marker recorded by Biber et al. (1999: 878). We thus exclude such instances and include only those cases where so clearly carries inferential/resultive meaning, as in (3).

[\$Tyke.\$] Why, you know, before you were a Lord, your name was Mr. Philip; so I got some gunpowder and marked an F on his neck, because F stands for Philip - yes yes - it struck me as proper.

(Drama, Morton, 1800-30, p. 70)

\subsubsection{Data selection}

As conjuncts do not have any morphological features in common, it would technically be necessary to scrutinize the entire corpus manually to ensure complete recall. However, such an approach would be unfeasible considering the amount of material. As the vast majority of conjuncts consist of adverbs (Biber et al. 1999: 768-9), and as most of these adverbs form a closed class (Quirk et al. 1985: 634), ${ }^{2}$ we opted for a semi-

\footnotetext{
${ }^{2}$ As enumerative conjuncts (i.e. first(ly), second(ly), etc.) are potentially an open class (Quirk et al 1985: 634; Lenker 2010: 222), we searched for such conjuncts in ascending order until no conjunct realizations were attested; for instance, as there were four instances of thirdly as a conjunct but no instances of fourthly, it was assumed that fifthly, sixthly, etc. would not occur as conjuncts in the material. A similar procedure was followed as regards numerals or letters, which can potentially function as enumerative conjuncts: non-case-sensitive searches were run for letters and Roman and Arabic numerals followed by
} 
Peter J. Grund and Erik Smitterberg. 2014 "Conjuncts in Nineteenth-Century English: Diachronic Development and Genre Diversity." English Language and Linguistics 18(1): 157-181. (Accepted manuscript version; post-peer review)

automatic retrieval process where potential conjuncts were retrieved by a concordancer and then inspected manually so that only actual conjuncts would be included in the counts. We used the list of conjuncts given in Quirk et al. (1985: 634-6) as a starting point. This list is claimed to include 'all adverb realizations ... as well as some frequently occurring prepositional phrases and noun phrases' (Quirk et al. 1985: 634). This list was then checked against inventories of conjuncts provided by Mittwoch, Huddleston \& Collins (2002), Biber et al. (1999), and Lenker (2010), to ensure comprehensive coverage. $^{3}$

However, some items that have been included as conjuncts by some scholars but not by others were excluded from our searches. Most importantly, we excluded members of Lenker's (2010) source domain TRUTH/FACT such as truly and surely. Lenker (2010: 114-30) argues that adverbs from this domain can mark contrastive/concessive and transitional relationships in texts. However, we consider such adverbials disjuncts rather than conjuncts, as they are mainly concerned with 'the speaker's "authority" for (or the speaker's comment on) the accompanying clause' rather than with the speaker's 'assessment of how he views the connection between two

parentheses or full stops, e.g. a) and 1., in ascending order until no such conjuncts occurred in the corpus texts.

${ }^{3}$ Lenker (2010: 10, 96-7) includes in her study 'lexicalized phrases' such as after all and all the same, but excludes 'non-lexicalized phrases' such as in other words and on the contrary. She distinguishes the two groups on the basis of (a) whether at least some of the characteristics of the original construction have been lost and (b) whether the meaning can be reconstructed from that of the component parts. Since we are uncertain about the theoretical underpinning of this distinction and since both groups of phrases are attested as conjuncts in Present-Day English as well as in our own material, we include both of Lenker's types in our study. 
Peter J. Grund and Erik Smitterberg. 2014 "Conjuncts in Nineteenth-Century English: Diachronic Development and Genre Diversity.” English Language and Linguistics 18(1): 157-181. (Accepted manuscript version; post-peer review)

linguistic units' (Quirk et al. 1985: 631-2; cf. Meurman-Solin 2011: section 2). ${ }^{4} \mathrm{We}$ could not find examples where a clear conjunctive meaning was present without considerable disjunctive colouring. In terms of other, variably-treated items, such as well, for, here, indeed, either, neither, and nor, we either did not find any conjunctive uses after analysing randomly selected samples (here and indeed), or adopted the analysis suggested by studies that excluded the items (for for, see Quirk et al. 1985: 920-8; for well, see Greenbaum 1969: 27-8; Biber et al. 1999: 1086-7; for either, see Quirk et al. 1985: 604; for neither and nor, see the list in Greenbaum 1969: 35-37).

A full list of the conjunct forms searched for is given in Appendix 1. Every instance of the forms was retrieved with the aid of the concordancer program in the WordSmith Tools software suite. Both authors went through all concordances independently, and the final database (in Microsoft Access) included only instances that both authors agreed were conjuncts. We restricted the scope of the study to conjuncts that linked linguistic material above the phrase level; the same strategy was followed by Lenker (2010: 4). For instance, in (4), the linguistic material linked by above all comprises noun phrases, whereas above all in example (5) links two main clauses.

(4) $[\ldots]$ let me observe that the yellow leather flesh of old men, the ill drawn \& ugly young women, \&, above all, the dawbed black \& yellow shadows that are found in most fine, ay, \& the finest pictures, I altogether reject as ruinous to Effect, tho' Connoisseurs may think otherwise.

\footnotetext{
${ }^{4}$ In addition, at least some of Lenker's (2010: 114) adverbial connectors from the domain TRUTH/FACT, e.g. in fact, can be the answer to a yes/no question (alone and/or accompanied by no or yes), a criterion which Greenbaum (1969: 25) claims that disjuncts but not conjuncts meet.
} 
Peter J. Grund and Erik Smitterberg. 2014 "Conjuncts in Nineteenth-Century English: Diachronic Development and Genre Diversity." English Language and Linguistics 18(1): 157-181. (Accepted manuscript version; post-peer review)

(Letters, Blake, 1800-30, p. 41)

Have you yet received a copy of Shelley's poem he has ordered one to be sent - and above all have you read Mandeville \& what do you think of it.

(Letters, Shelley, 1800-30, p. 46)

Only example (5) was thus entered into the database. ${ }^{5}$

A few examples of the classification process are provided below in order to increase the replicability of our selection of data; we focus on an item that has both conjunctive and non-conjunctive functions, viz. then (for the potential ambiguity and overlapping meanings of adverbials, see Hasselgård 2010: 302-3). In most cases, deciding whether an item was a conjunct or not was relatively straightforward. For instance, in (6), then clearly has the conjunctive function of providing an inferential link between the preceding and following discourse; the presence of the temporal adverbial when Roger Tichborne came of age makes it highly unlikely that then would also refer to a point in time. By contrast, in (7), a temporal and thus adjunctive reading is highly likely, given the preceding linguistic context.

(6) Did you leave in the summer or the winter? - In the summer.

Leaving Miss Braine still there? - Yes.

That is the summer of the year in which the ball was? - Yes.

\footnotetext{
${ }^{5}$ Note that the requirement that the conjunct should link clausal material does not mean that we restricted our attention to paratactic linking. For instance, the conjunct then may correlate with a subordinator such as if in a sentence like If you knew this all along, then you could have told me (Quirk et al. 1985: 643); such conjuncts were also included in our counts.
} 
Peter J. Grund and Erik Smitterberg. 2014 "Conjuncts in Nineteenth-Century English: Diachronic Development and Genre Diversity.” English Language and Linguistics 18(1): 157-181. (Accepted manuscript version; post-peer review)

Then you were there when Roger Tichborne came of age, were not you? - No.

(Trials, Tichborne, 1870-1900, p. 2,405)

(7) $[\$ Q . \$]$ I believe you came to his house again in the afternoon of the same day?

- [\$A.\$] I did, Sir.

[\$Q.\$] About what time was that?

[\$A.\$] I think it must have been betwen two and three.

[\$Q.\$] And what room was he in then?

[\$A.\$] In the same room in which I had left him.

(Trials, Angus, 1800-30, p. 92)

However, there were also cases where the linguistic context was not sufficient to resolve the ambiguity. Consider (8).

[...] and William says that he thinks it folly for them both to go to Wales together (a hunting) they had best take two different roads (as the Kings sons used to do when they went to seek their Fortunes) and then they will travel over twice as much ground with the same expence.

(Letters, Hutchinson, 1800-30, p. 9)

Although a conjunctive, inferential reading where then means 'if they take two different roads' is perfectly plausible, an adjunctive, temporal interpretation 'after they have taken two different roads' cannot be ruled out. As both of these subordinate-clause 
Peter J. Grund and Erik Smitterberg. 2014 "Conjuncts in Nineteenth-Century English: Diachronic Development and Genre Diversity." English Language and Linguistics 18(1): 157-181. (Accepted manuscript version; post-peer review)

readings are compatible with will + infinitive in the matrix clause, tense choice does not disambiguate the example. Such cases were ultimately left out of the counts.

The analysis and selection process resulted in 2,318 instances of conjuncts being included in the counts. The raw frequencies of conjuncts by period and genre are given in table 3.

Table 3. Conjuncts by period and genre in CONCE (periods 1 and 3)

\begin{tabular}{|l|r|r|r|r|r|r|r|l|}
\hline Period & Debates & Drama & Fiction & History & Letters & Science & Trials & \multicolumn{1}{l|}{ Total } \\
\hline 1 & 83 & 142 & 146 & 73 & 512 & 180 & 134 & 1,270 \\
\hline 3 & 74 & 90 & 70 & 89 & 339 & 228 & 158 & 1,048 \\
\hline Total & 157 & 232 & 216 & 162 & 851 & 408 & 292 & 2,318 \\
\hline
\end{tabular}

\section{RESULTS}

\subsection{Distribution according to time and genre}

To enable comparison between text samples of different sizes, raw frequencies of the conjuncts that resulted from our CONCE searches have been normalized to a text length of 1,000 words. The results are given in table 4 .

Table 4. Conjuncts per 1,000 words by period and genre in CONCE (periods 1 and 3)

\begin{tabular}{|l|r|r|r|r|r|r|r|r|}
\hline Period & \multicolumn{1}{|c|}{ Debates } & Drama & \multicolumn{1}{c|}{ Fiction } & \multicolumn{1}{c|}{ History } & Letters & Science & \multicolumn{1}{c|}{ Trials } & \multicolumn{1}{c|}{ Total } \\
\hline 1 & 4.17 & 4.54 & 3.47 & 2.36 & 4.21 & 4.73 & 2.15 & 3.67 \\
\hline 3 & 3.71 & 3.09 & 2.32 & 2.91 & 3.73 & 7.45 & 2.34 & 3.51 \\
\hline Total & 3.94 & 3.84 & 2.99 & 2.64 & 4.00 & 5.94 & 2.25 & 3.59 \\
\hline
\end{tabular}


Peter J. Grund and Erik Smitterberg. 2014 "Conjuncts in Nineteenth-Century English: Diachronic Development and Genre Diversity." English Language and Linguistics 18(1): 157-181. (Accepted manuscript version; post-peer review)

If only the period totals are considered, there appears to be little change in diachrony: the difference between periods 1 and 3 is a mere 0.16 occurrences per 1,000 words. However, as table 4 reveals, this apparent stability hides considerable differences among genres and changes within individual genres.

It is clear that texts belonging to genres with narrative concerns contain fewer conjuncts than do texts from other genres. The three genres with the lowest frequency of conjuncts are Trials, History, and Fiction. Of these, Trials and Fiction were characterized by 'markedly narrative' concerns in Geisler's (2002: 259) factor score analysis of CONCE (History was not statistically distinct from Debates, Letters, and Drama). As Biber et al. (1999: 882-3) show, this correlation is connected to textual organization: narrative genres are often structured so that the textual order of presentation parallels the chronological order of events, which reduces the need for other overt markers of cohesion, such as conjuncts (cf. Greenbaum 1969: 80; Lenker 2010: 13-15). While History texts are not as clearly narrative as those from Trials and Fiction, they too are characterized by a chronological structure. The resulting low frequency of conjuncts in these genres is perhaps especially striking as regards causal relationships: the default assumption is that a preceding event causes the next one, and this relationship can then be left unmarked (cf. Lenker 2010: 13; see also 4.2.2). In (9), for instance, the witness presumably opens the door because Mrs Bartlett knocks on it and identifies herself, and gets up in response to her message, but there are no overt signals in the text that express these causal relationships.

(9) $[\$ Q . \$]$ What attracted your attention? Did somebody knock at the door?[\$A.\$] Yes, I heard a knock at the door. 
Peter J. Grund and Erik Smitterberg. 2014 "Conjuncts in Nineteenth-Century English: Diachronic Development and Genre Diversity." English Language and Linguistics 18(1): 157-181. (Accepted manuscript version; post-peer review)

[\$Q.\$] Did you find that Mrs. Bartlett was at the door? - [\$A.\$] Yes.

[\$Q.\$] Did you open the door? - [\$A.\$ Yes.

[\$Q.\$] What did she say? - [\$A.\$] She asked me to come down.

[\$Q.\$] As if she was speaking to you now? - [\$A.\$] She said, "Come down; I think Mr. Bartlett is dead.”

[\$Q.\$] Had you ever spoken to her before? - [\$A.\$] Never.

[\$Q.\$] Did you at once get up? - [\$A.\$] Yes.

(Trials, Bartlett, 1870-1900,p.43)

As regards the other genres, Debates, Drama, and Letters exhibit similar overall frequencies, while Science stands out with a markedly higher frequency of conjuncts than any other genre. Interestingly, this difference between Science and the other genres in CONCE appears to be the result of a development taking place within the nineteenth century. In period 1, the frequency of conjuncts in Science is not substantially different from that of Debates, Drama, and Letters; but whereas the three latter genres, as well as Fiction, ${ }^{6}$ display decreases in frequency of between 11 and $33 \%$, the incidence of conjuncts in Science increases by as much as $57 \%$. This may indicate that scientific

\footnotetext{
${ }^{6}$ Using Smitterberg's (2005: 70-1) division of the Fiction texts into dialogue and non-dialogue, it is possible to calculate separate frequency values for these samples. While both dialogic and narrative passages display a decrease in the frequency of conjuncts, values are much higher in dialogue, which is quite close to Drama with 4.68 occurrences per 1,000 words in period 1 and 3.16 in period 3. Fictional narrative, which contains 2.94 occurrences per 1,000 words in period 1 and 1.72 in period 3 , is closer to History and Trials (cf. Greenbaum 1969: 80).
} 
Peter J. Grund and Erik Smitterberg. 2014 "Conjuncts in Nineteenth-Century English: Diachronic Development and Genre Diversity." English Language and Linguistics 18(1): 157-181. (Accepted manuscript version; post-peer review)

writing underwent genre development in this regard over the 1800 s. $^{7}$ Biber \& Finegan (1997: 268-72) show that scientific texts have become more abstract and less narrative since the mid-seventeenth century; as conjuncts load as an abstract feature on Dimension 5 of their analysis and are rarer in narrative than in non-narrative writing, both developments would tally with an increase in the frequency of conjuncts across the nineteenth century. ${ }^{8}$ The frequent use of conjuncts in Science (especially at the end of the century) also fits with findings for twentieth-century English. In Greenbaum's (1969: 80) study, science is one of two text categories with the highest frequency of conjuncts per 1,000 words at 6.9 instances, and Biber et al. (1999: 880-1) show that conjuncts are most frequent in academic texts. Biber et al. (1999: 880) attribute this tendency to the importance of presenting clear, explicitly linked arguments in this text category. What we may be seeing in the frequency development of conjuncts in Science, then, is perhaps an increased importance of argumentation in scientific writing over the nineteenth century.

It is also worth noting that the only other genre in CONCE that exhibits a considerable growth in conjunct frequency (23\%) between periods 1 and 3 is History, the other written expository genre in the corpus. This change may indicate that

\footnotetext{
${ }^{7}$ This hypothesis is supported by a look at the individual texts. While the frequency of conjuncts in the Science texts from period 1 varies between 1.93 and 7.15 occurrences per 1,000 words, the three Science texts from period 3 are remarkably similar, with 7.19 to 7.79 occurrences per 1,000 words. Although the number of texts from each period is too low to allow safe conclusions, these results may indicate that scientific writing developed towards a more or less uniformly extensive use of conjuncts as a genrespecific feature in the course of the nineteenth century.

${ }^{8}$ Dimension 5 is called 'Abstract vs. non-abstract information' in Biber (1988) and 'Non-impersonal vs. impersonal style' in Biber \& Finegan (1997); we use the terminology from Biber (1988) in this study.
} 
Peter J. Grund and Erik Smitterberg. 2014 "Conjuncts in Nineteenth-Century English: Diachronic Development and Genre Diversity." English Language and Linguistics 18(1): 157-181. (Accepted manuscript version; post-peer review)

increased reliance on conjuncts as cohesive markers characterizes expository writing in general during this time. In other words, History writing takes up an intermediate position regarding conjunct frequency in period 3 because it is affected by two opposing genre norms: a tendency for chronologically structured genres not to employ many conjuncts and a tendency for written expository genres to do so.

Biber \& Gray’s (2010: 15-16) diachronic study of linking adverbials (i.e. our conjuncts) in academic writing presents results that are partly at odds with the above account. According to their data, conjuncts have become less frequent in academic prose since the early eighteenth century (except for a period of stability in the 1800s). This is difficult to reconcile with our finding that both genres which comprise academic prose (Science and History) display clear increases in frequency over the nineteenth century. It is possible that differences between the corpora used, especially in terms of the subgenres within academic prose included, account for this discrepancy. Some support for this assumption comes from the results in Biber et al. (1999: 880-1). Using a different corpus, they report higher frequencies of conjuncts in late-twentieth-century academic prose (>7 per 1,000 words) than Biber \& Gray (2010) do (between 4.5 and 5.5 per 1,000 words). Another possibility is that different methods were used to retrieve conjuncts from the material. Biber \& Gray (2010) do not account for how their data were selected, which makes comparison difficult. If the algorithms devised by Biber (1988) were used to select conjuncts in their texts, that method would not lead to the same dataset that our combination of semi-automatic retrieval and manual postprocessing would identify (see below).

Some of the developments in the frequency of conjuncts shown in our study tally with the results of Geisler's (2002) factor score analysis of CONCE. In this 
Peter J. Grund and Erik Smitterberg. 2014 "Conjuncts in Nineteenth-Century English: Diachronic Development and Genre Diversity." English Language and Linguistics 18(1): 157-181. (Accepted manuscript version; post-peer review)

framework, conjuncts load as a feature marking abstract style on Dimension 5 of the analysis (the other features involved are passives and adverbial subordinators). We might thus expect an increase in the incidence of conjuncts to correlate with a change towards a more abstract style, while a decrease would indicate that the genre becomes less marked for abstractness. The decreases in conjunct frequency noted in Drama, Fiction, and Letters are indeed matched by these genres becoming significantly less marked for abstractness in Geisler (2002). The remaining four genres in CONCE do not change statistically in Geisler's analysis, however; even Science is stable on Dimension 5 , the huge increase in the frequency of conjuncts notwithstanding. It is possible that this discrepancy is due to stability in the frequency of other features that load on that dimension; as Gustafsson (2006: 114) shows, the frequency of BE-passives in Science is stable in diachrony, which would make a change on Dimension 5 less likely. In addition, the algorithms used in Geisler (2002), which were originally formulated by Biber (1988: 239-40), would not select the same dataset that we have arrived at. For example, in Science, at least $37 \%$ of conjuncts in period 1 and $47 \%$ of conjuncts in period 3 would not be selected by Biber's algorithms, which exclude several ambiguous forms such as then and yet. On the other hand, most of Biber's (1988) algorithms do not distinguish between clause-level and phrase-level conjuncts, and would thus include examples that we have excluded. Comparisons between Geisler's (2002) results and those of the present study should therefore be treated with some caution.

Another important consequence of the changes in conjunct frequency between periods 1 and 3 is that cross-genre differences in the incidence of conjuncts grow. In period 1, the difference in frequency between the genres with the highest (Science) and the lowest (Trials) frequency of conjuncts is 2.58 occurrences per 1,000 words. By 
Peter J. Grund and Erik Smitterberg. 2014 "Conjuncts in Nineteenth-Century English: Diachronic Development and Genre Diversity." English Language and Linguistics 18(1): 157-181. (Accepted manuscript version; post-peer review)

contrast, the corresponding difference in period 3, when Science displays the highest and Fiction the lowest frequency of conjuncts, is 5.13 occurrences per 1,000 words, an increase of $98 \%$. Conjuncts thus fit into a general pattern of increasing linguistic genre differentiation during the nineteenth century that has previously been noted both for individual linguistic features (see, for instance, Smitterberg 2005: 67 for the progressive and Smitterberg 2012: 201 for NOT-contraction) and in multi-feature/multi-dimensional analyses such as Biber \& Finegan (1997).

While several of these changes can be explained in terms of a colloquialization of popular writing, in which the incidence of features characteristic of spoken discourse increases, there are also cases where specialized expository writing is innovative; an increased use of conjuncts appears to be one such case. This agrees with Biber \& Gray's (2011) findings about developments in noun phrase structure over the past few centuries, where academic writing appears to be in the forefront of change. However, as Biber et al. (1999: 880) show for Present-Day English, both conversation and academic writing in fact contain a large number of conjuncts. Greenbaum (1969: 80) even records 6.9 instances of conjuncts per 1,000 words for both conversation and science. If conjuncts were frequently employed in conversation in nineteenth-century English, we do not see a clear reflection of such patterns in speech-related genres in CONCE such as Drama, Trials, Fiction (dialogue), and, to some extent, Letters. We will return to some differences between speech-related genres and other genres in the next section. 
Peter J. Grund and Erik Smitterberg. 2014 "Conjuncts in Nineteenth-Century English: Diachronic Development and Genre Diversity." English Language and Linguistics 18(1): 157-181. (Accepted manuscript version; post-peer review)

\subsection{Semantic types, individual conjuncts, and author styles}

In the following sections, we consider the distribution of different semantic categories of conjuncts. Quirk et al. (1985: 634-640) and Biber et al. (1999: 875-883) both discuss the different types into which conjuncts can be grouped based on the kind of relationship they express between stretches of text (see also Halliday \& Hasan 1976: 238-71; Halliday 1994: 324; Lenker 2010: 40). As we will show, the genres in CONCE exhibit strikingly different profiles with regard to the proportions of semantic types. Given that Science displayed such a dramatic change in conjunct frequency, we also discuss the incidence of types from a diachronic perspective in this genre. We will comment on the use of individual conjuncts and discuss the stylistic preferences of individual authors, where relevant.

As regards frequency, our conjuncts fall into two distinct groups. Six conjuncts reveal triple-digit frequencies: however (323), then (314), so (283), therefore (213), yet (211), and now (186). ${ }^{9}$ The remaining conjuncts (ca. 85) range in frequency between one (e.g. similarly) and 44 (thus). These patterns to some extent mirror trends in Present-Day English, where so, then, however, and therefore are also among the most common in Biber et al.'s (1999: 887) study of conversation and academic prose. However, differences are also evident, as yet is relatively rare in their material, and though, thus, and for example are relatively frequent. As we outline patterns for individual conjuncts, we will concentrate on the first category, where the numbers are robust across time and text categories, but we will also provide some limited remarks on the less common conjuncts when relevant.

\footnotetext{
${ }^{9}$ No distinction is made between different semantic categories of, for example, so here (cf. note 10).
} 
Peter J. Grund and Erik Smitterberg. 2014 "Conjuncts in Nineteenth-Century English: Diachronic Development and Genre Diversity.” English Language and Linguistics 18(1): 157-181. (Accepted manuscript version; post-peer review)

\subsubsection{Semantic classification and individual conjuncts}

Our categorization of semantic types is largely based on Quirk et al.'s (1985) and Biber et al.'s (1999) groupings, but for the purposes of the present quantitative study, we chose to work with relatively few types in order to reach statistically solid results and avoid having to classify individual instances as indeterminate between subtypes. We recognize five categories in our set-up: Apposition, Contrast, List/Summary, Result/Inference, and Transition.

Conjuncts marking Apposition, such as that is and for example, signal that 'the second unit of text is to be treated either as equivalent to or as included in the preceding unit' (Biber et al. 1999: 876). The most frequent conjunct expressing Apposition in the corpus is for instance, as in (10), with 30 occurrences. ${ }^{10}$

(10) Though in extra legs parts may be deficient or malformed, structures which in the normal leg are central to the point of origin of the extra legs are not repeated in them. For instance, if the extra legs spring from the trochanter they do not contain parts of the coxa, if from the second tarsal joint, the first tarsal joint is not represented in them, and so on.

(Science, Bateson, 1870-1900, p. 476)

\footnotetext{
${ }^{10}$ Note that these raw frequencies denote the frequency of conjuncts as they occur within a particular semantic type. Conjuncts that can belong to several types may thus have a higher total frequency in the corpus texts; for instance, so occurs twelve times expressing Transition in the material in addition to its 271 occurrences as a Result/Inference conjunct.
} 
Peter J. Grund and Erik Smitterberg. 2014 "Conjuncts in Nineteenth-Century English: Diachronic Development and Genre Diversity." English Language and Linguistics 18(1): 157-181. (Accepted manuscript version; post-peer review)

The Contrast category includes conjuncts which indicate that the second unit of text is a reformulation of or replacement for the first unit (e.g. rather), that the second unit contrasts with the first unit (e.g. on the contrary), or that the second unit is unexpected in the light of the first unit. The most frequent conjunct in this category, however (323 instances), which is found in all genres, tends to signal the last, concessive, type of relationship, as in (11). This is also the most common contrastive conjunct in Altenberg's (1986: 16) study based on the London-Lund Corpus and LOB. Interestingly, in Biber et al.'s (1999: 887) comparison of conjuncts in Present-Day English conversation and academic writing, however is clearly characteristic of the latter genre, while though is a frequent marker of contrast in conversation. This division may not have been present in the nineteenth century. As shown in, for instance, Geisler (2002), the division of the genres in CONCE into an expository group (Debates, History, and Science) and a non-expository group (Drama, Fiction, Letters, and Trials) is of particular importance as regards the distribution of linguistic features across the corpus texts: formal linguistic features occur chiefly in expository genres. Although the non-expository genres Drama and Trials reveal the lowest frequency per 1,000 words of however ( 0.22 and 0.15 respectively), Letters, another non-expository genre, exhibits the highest normalized frequency of all genres in CONCE (at 0.70). Though, on the other hand, is only attested once as a conjunct in Letters (and once in Fiction and four times in Drama). It is thus likely that however was not as marked for formality in the 1800 s as it is today.

(11) "There appeared such a perfectly good understanding among them all -" he began rather quickly, but checking himself, added, "however, it is impossible 
Peter J. Grund and Erik Smitterberg. 2014 "Conjuncts in Nineteenth-Century English: Diachronic Development and Genre Diversity." English Language and Linguistics 18(1): 157-181. (Accepted manuscript version; post-peer review)

for me to say on what terms they really were - how it might all be behind the scenes. I can only say that there was smoothness outwardly. [...]" (Fiction, Austen, 1800-30, p. II.109)

Although the use of however in CONCE does not suggest a clear line between expository and non-expository texts, other conjuncts are indicative of such a distinction; for example, the conjunct only (33 occurrences) appears only in the non-expository genres Drama, Fiction, Letters, and Trials.

Conjuncts in the List/Summary category may structure a list by ordering the items using forms such as first(ly), second(ly), then, and finally. The most frequent conjunct with an enumerating function is then (23 instances). Other functions that belong to this category are the expression of an additional point which is presented as compatible with one previously made (using conjuncts such as equally, likewise, and similarly) and the expression of a summary of several preceding items (e.g. to sum up); clear instances of the latter two functions are very rare in our material, however, amounting to only one instance of each conjunct given above. More common is the combination of similarity and reinforcement. The most frequent conjunct in this category is moreover (22 occurrences), as in (12), which is attested in all genres.

(12) A British officer declared that men were wanted whose policy would be just, not inhuman, "whose manners are not haughty but conciliatory, whose language and views are those of English statesmen, not of revolutionary tribunals." The military arrangements were, moreover, defective. (History, Walpole, 1870-1900, pp. VI.302-303) 
Peter J. Grund and Erik Smitterberg. 2014 "Conjuncts in Nineteenth-Century English: Diachronic Development and Genre Diversity." English Language and Linguistics 18(1): 157-181. (Accepted manuscript version; post-peer review)

In the Result/Inference category, by far the most frequent conjuncts are inferential then, as in (13), so, and therefore, with 274, 271, and 213 occurrences, respectively.

(13) The hon. gent. had said, that if lord Wellington had closed a long life of service by a brilliant victory, as other officers had done, then he would have merited the same reward.

(Debates, 1800-30, p. XV.449)

Some generic patterns emerge in the use of these conjuncts. The frequency of therefore is far higher in the expository genres Science and Debates $(0.92$ and 0.70 per 1,000 words, respectively) than in the remaining genres, where it ranges from 0.07 in Drama to 0.36 in Letters. The low frequency in History (0.20), another expository genre, can perhaps be accounted for by the fact that signalling cause and effect or inference is overall relatively rare in this genre, probably owing to its primarily chronological organization (see 4.2.2). So, on the other hand, which is given as characteristic of conversation in Present-Day English by Biber et al. (1999: 887), is frequent chiefly in texts that are characterized by neither narrative concerns (which would keep down the incidence of resultive markers) nor formal production circumstances (which would favour other items, like therefore): Drama (0.68), dialogue in Fiction (0.51), and Letters (0.92). This distribution suggests that the use of so was characteristic of speech in the nineteenth century as well. 
Peter J. Grund and Erik Smitterberg. 2014 "Conjuncts in Nineteenth-Century English: Diachronic Development and Genre Diversity." English Language and Linguistics 18(1): 157-181. (Accepted manuscript version; post-peer review)

Conjuncts that signal Transition, finally, mark the second unit of discourse as

only tangentially related or as unrelated to preceding units. By far the most frequent conjunct marking Transition is now, with 186 occurrences, as in (14).

(14) [\$Q.\$] Who was there at the Breakfast?

[\$A.\$] The Master.

[\$Q.\$] The master - that is Mr. Angus?

[\$A.\$] Yes, Mr. Angus and herself, and the three children.

[\$Q.\$] Now, after breakfast, did Miss Burns ask you for any thing?

[\$A.\$] Yes, about an hour and a half after breakfast.

(Trials, Angus, 1800-30, p. 30)

Now is predominantly used in Trials (109 out of 186 instances), while it is rare to nonexistent in the rest of the genres, except for Drama (32 instances). This overall pattern is undoubtedly tied in with the function of now and other conjuncts belonging to this category. In Trials, now appears to be used by lawyers to signal a shift of topic or a transition to a new topic, and to draw the witness's attention to the coming question. Other conjuncts that mark Transition in the material include by the bye and meanwhile.

\subsubsection{Semantic types and genre}

The distribution of semantic types according to genre is given in table 5 . 
Peter J. Grund and Erik Smitterberg. 2014 "Conjuncts in Nineteenth-Century English: Diachronic Development and Genre Diversity." English Language and Linguistics 18(1): 157-181. (Accepted manuscript version; post-peer review)

Table 5. Conjuncts by genre and semantic type

\begin{tabular}{|c|c|c|c|c|c|c|c|c|c|c|c|}
\hline Genre & \multicolumn{2}{|c|}{ Apposition } & \multicolumn{2}{|c|}{ Contrast } & \multicolumn{2}{|c|}{ List/Sum. } & \multicolumn{2}{|c|}{ Result/Inf. } & \multicolumn{2}{|c|}{ Transition } & \multirow[t]{2}{*}{ Total } \\
\hline & $\#$ & $\%$ & \# & $\%$ & \# & $\%$ & \# & $\%$ & \# & $\%$ & \\
\hline Deb & 8 & 5 & 8 & 42 & 4 & 8 & 8 & 36 & 9 & & 157 \\
\hline & 4 & & & & 1 & & 121 & 52 & 39 & 16 & 232 \\
\hline Fic & 5 & & 1 & & 1 & & & 3 & 11 & & 216 \\
\hline His & 1 & & 7 & 5 & 2 & 13.6 & 41 & 25.3 & & & 162 \\
\hline Let & - & & & & 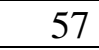 & & & 40.5 & 9 & & 851 \\
\hline Scie & 3 & & 123 & 30 & 42 & 10. & 19 & 48.0 & 13 & 3 & 408 \\
\hline Trial & 1 & & 5 & & 1 & & & 36.6 & 109 & 37.3 & 292 \\
\hline Total & 93 & 4.0 & 884 & 38.1 & 175 & 7.5 & 935 & 40.3 & 231 & 10.0 & 2,318 \\
\hline
\end{tabular}

In CONCE as a whole, the distribution of conjuncts is dominated by two types, viz.

Contrast and Result/Inference, which together account for almost four fifths of the data.

This is similar to the results shown by Biber et al. (1999: 880) for Present-Day English

(cf. also Morrow 1989: 245). However, table 5 also shows that there is considerable

variation across genres with regard to the proportions of types. These cross-genre

differences, which are statistically significant, ${ }^{11}$ indicate that some of the genres have

specific ties with individual semantic fields. We will therefore consider genre-specific

distributions in detail below.

The Debates genre is fairly close to the results for all text categories taken together. However, the relatively high percentage of List/Summary conjuncts is noteworthy, as Debates is the only speech-related genre with a proportion above the corpus mean. In Debates, such conjuncts help to structure each speaker's long turns of extended argumentation, as in (15).

${ }^{11}$ d.f. $=24 ; \chi^{2}=461 ; \mathrm{p}<0.001$ 
Peter J. Grund and Erik Smitterberg. 2014 "Conjuncts in Nineteenth-Century English: Diachronic Development and Genre Diversity." English Language and Linguistics 18(1): 157-181. (Accepted manuscript version; post-peer review)

(15) [...] Lastly, the system under which counties have been divided into onemembered districts, and London has been divided into twenty-seven different boroughs, has greatly increased the number of plural votes. In the first place, a man may have as many votes for different county districts as he has freehold qualifications in them. Secondly, he may have as many occupation votes as he has bona fide residences in different constituencies. [...]

(Debates, 1870-1900, p. IV.1,184)

In (15), lastly marks the speaker's arrival at the last major point he wishes to make. However, that point is then further subdivided by in the first place and secondly. List/Summary conjuncts are important for listeners to be able to understand - and respond to - spoken arguments of such complexity.

Drama clearly favours Result/Inference and, to a lesser extent, Transition conjuncts, while Contrast is comparatively poorly represented. These tendencies are remarkably consistent across the Drama texts included in CONCE. The proportion of Result/Inference conjuncts is the highest for any genre in the corpus. The commonest conjuncts in that category are then (68 occurrences), as in (16), and so (41 instances; see also 4.2.1).

\section{[\$HANNAH.\$]}

Master, is what you've told me your only chance of getting off unknown?

\section{[\$THE DEAN.\$]}

It is the sole remaining chance of averting a calamity of almost national importance. 
Peter J. Grund and Erik Smitterberg. 2014 "Conjuncts in Nineteenth-Century English: Diachronic Development and Genre Diversity.” English Language and Linguistics 18(1): 157-181. (Accepted manuscript version; post-peer review)

[\$HANNAH.\$]

Then you're as done as that joint in my oven!

(Drama, Pinero, 1870-1900, pp. 112-113)

Then often marks Result/Inference in contexts like that in (16): a character uses turninitial then in the sense 'in that case' to express an inference based on another character's previous utterance. These instances of then have the double function of clarifying the relationship between turns to the characters within the play as well as to the audience.

Fiction displays almost the opposite pattern, with the second lowest proportion of Result/Inference conjuncts and the second highest percentage of Contrast conjuncts. This distribution tallies with Biber et al.’s (1999: 880) results for Present-Day English, which show that Contrast conjuncts are more frequent than Result/Inference conjuncts in this genre. As in the corpus as a whole, however (44 occurrences) and yet (27 instances) account for the majority of Contrast conjuncts in Fiction. However, these results are chiefly due to the distribution of conjuncts in narrative passages. The proportions of the Contrast and Result/Inference types in fictional narration are quite close to those of History (60.3\% and $28.4 \%$, respectively), and it is likely that the chronological sequencing of events makes the overt expression of Result/Inference less necessary (see below). The proportions in fictional dialogue $(47.0 \%$ and $34.0 \%)$ are closer to those found in Debates; in addition, as in Drama, the most frequent conjunct in fictional dialogue is then expressing Result/Inference. Dialogue in Fiction thus shows affinities with other speech-related genres in these respects. Although Contrast conjuncts outnumber Result/Inference conjuncts in all fiction texts in CONCE, Mary 
Peter J. Grund and Erik Smitterberg. 2014 "Conjuncts in Nineteenth-Century English: Diachronic Development and Genre Diversity." English Language and Linguistics 18(1): 157-181. (Accepted manuscript version; post-peer review)

Shelley stands out in her preference for marking contrastive relationships in this way: 18 of the 22 conjuncts in her text (The Last Man) are of the Contrast type, and 10 of those 18 are instances of yet, as in (17).

(17) A variety of feelings urged Perdita to shed double magnificence over the scene; yet, as she arrayed herself for the evening gala, she wondered herself at the pains she took, to render sumptuous the celebration of an event which appeared to her the beginning of her sufferings.

(Fiction, Shelley, 1800-1830, p. I.277-8)

In History, which, like Fiction, is characterized by chronologically structured text, more than half of all conjuncts express Contrast. ${ }^{12}$ Concessive however (38 occurrences) and yet (33 instances) are the most frequent conjuncts in this field, but History writing is also characterized by a fairly large number of contrastive relationships being expressed by on the other hand, as in (18).

(18) The university of Oxford was tainted to the core with jacobite prejudices; but it must be added that it never stood so low in respectability as a place of education. The government, on the other hand, was studious to promote distinguished men; and doubtless the hierarchy in the first sixty years of the

\footnotetext{
${ }^{12}$ History also displays the highest proportion of List/Summary conjuncts in CONCE, but this result is due especially to the occurrence of Roman numerals as conjuncts in a long enumeration in Henry Hart Milman's History of the Jews and may thus not be valid for the genre as a whole.
} 
Peter J. Grund and Erik Smitterberg. 2014 "Conjuncts in Nineteenth-Century English: Diachronic Development and Genre Diversity." English Language and Linguistics 18(1): 157-181. (Accepted manuscript version; post-peer review)

eighteenth century might very advantageously be compared, in point of conspicuous ability, with that of an equal period that ensued.

(History, Hallam, 1800-30, pp. III.334-5)

In History, on the other hand typically signals an antithetic relationship between two entities, which are compared in a more or less evaluative manner, as in (18). All History texts evince a preference for Contrast conjuncts over items belonging to other semantic fields. In contrast, the occurrence of Apposition and Transition conjuncts is negligible in History (1 occurrence each of for instance and meanwhile), and Result/Inference conjuncts account for a smaller proportion of the conjuncts than in any other genre in the corpus. To a certain extent, the dearth of Result/Inference and Transition conjuncts and the resulting high proportion of Contrast conjuncts - can be explained with reference to the style of History texts: as chronological order frequently helps to structure the texts in terms of both cause and effect and transitions between subjects, there is less need for explicit markers such as conjuncts.

The Letters genre is similar to Debates in lying quite close to the corpus mean for the various types, and it is difficult to see genre-specific patterns of usage. ${ }^{13}$ Although Contrast conjuncts are more frequent than Result/Inference conjuncts in the genre as a whole, there is some variation among the individual letter-writers regarding which semantic relationship is most often marked by conjuncts: William Blake, Sara Hutchinson, Robert Southey, Mary Wordsworth, Mary Butler, and Christina Rossetti make greater use of Result/Inference conjuncts, while Contrast is favoured by the

\footnotetext{
${ }^{13}$ Note that, since Letters is the most extensively sampled genre in CONCE, the distribution in this genre also affects the overall mean more than do results for other genres.
} 
Peter J. Grund and Erik Smitterberg. 2014 "Conjuncts in Nineteenth-Century English: Diachronic Development and Genre Diversity." English Language and Linguistics 18(1): 157-181. (Accepted manuscript version; post-peer review)

eleven remaining letter-writers. The most frequent Contrast conjunct by far is however (148 instances; see also 4.2.1), as in (19).

(19) He intended spending Friday Sat: \& part of Sunday, at Mr Cookson's as Mrs C had invited him so often he thought it was proper altho' I believe he had rather have remained at his books - however he took one in his pocket which he would ply when he was there, as he said James was always in the Warehouse which was no amusement to him - He has not written yet - but perhaps my Letter may not be sent off before next Wednesday.

(Letters, Hutchinson, 1800-30, p. 186)

Science exhibits a high proportion of Result/Inference conjuncts. However, this tendency is to some extent dependent on one text from period 1, viz. David Ricardo's On the Principles of Political Economy, and Taxation, with 77 Result/Inference conjuncts, the most common of which are then and therefore. The preference for these two conjuncts is also visible in the results for the genre as a whole. Then (68 occurrences) is the most frequent Result/Inference conjunct in Science, as was the case in Drama, the other genre with a high proportion of Result/Inference conjuncts. In addition, Apposition conjuncts account for a bigger share of the conjuncts in Science than in any other genre in CONCE, and the percentage of List/Summary conjuncts is second only to that in History. The most frequent type of Apposition marked by conjuncts is exemplification, using for instance (11 instances), as in (10) above, or for example (9 instances). Among List/Summary conjuncts, the most frequent item is again (11 occurrences), as in (20). This conjunct is by and large limited to Science. 
Peter J. Grund and Erik Smitterberg. 2014 "Conjuncts in Nineteenth-Century English: Diachronic Development and Genre Diversity." English Language and Linguistics 18(1): 157-181. (Accepted manuscript version; post-peer review)

(20) An outsider would think that if any one of these elementary bodies were taken as a standard, the weight of an equal volume of vapour of another substance under equal conditions would bear some relationship of a definite character to the atomic weight. This however is not the case. Again, among the questions to be considered as determining the atomic weights taken, is an assumed limitation of combination power, a so-called atomicity, according to which one substance is a monad, because it will combine with that same relative proportion of hydrogen which exists in half a water-molecule.

(Science, Lockyer, 1870-1900, p. 268)

Again typically marks the writer's returning to an item of information that has been mentioned previously, and the conjunct serves both to indicate this relationship with the previous discourse and to reinforce the point. As Result/Inference, Apposition, and List/Summary conjuncts can all be used to emphasize relationships such as inclusion, exemplification, and cause and effect between phenomena in the natural world, it is not surprising that they occur frequently in Science texts. The Transition category, in contrast, is very rare in Science as well as in History, the other written expository genre in CONCE; this sets written exposition clearly apart from dialogic genres such as Drama and Trials.

The Trials genre stands out from all other genres in its high proportion of Transition conjuncts; now, exemplified in (14) above, accounts for all 109 conjuncts marking Transition in Trials. On the other hand, the proportions of Contrast and List/Summary conjuncts are the lowest in CONCE. In all three cases, the genre closest 
Peter J. Grund and Erik Smitterberg. 2014 "Conjuncts in Nineteenth-Century English: Diachronic Development and Genre Diversity." English Language and Linguistics 18(1): 157-181. (Accepted manuscript version; post-peer review)

to Trials in terms of type distribution is Drama; it thus seems that a comparatively high percentage of Transition markers and low proportions of Contrast and List/Summary conjuncts together characterize dialogic texts. As Biber et al. (1999: 880) found that Transition conjuncts were rare in all four Present-Day English genres that they investigated, including Conversation, the distribution of conjuncts marking Transition in various types of speech-based and speech-related texts deserves further investigation.

The preference for now is fairly widespread in Trials: four of the six texts contain more than ten instances of this Transition marker, which is the only conjunct except then signalling Result/Inference that reaches double digits in any Trials text.

As Science stood out from the other genres in terms of frequency development over time, we also consider period-specific figures for this genre. The results are given in table 6. As the frequency of conjuncts in Science changes dramatically between periods 1 and 3, we present normalized frequencies rather than percentages in order to show developments within individual semantic types clearly.

Table 6. Conjuncts by period and semantic type in Science: raw frequencies and

frequencies per 1,000 words

\begin{tabular}{|l|r|r|r|l|r|l|r|r|r|r|r|}
\hline Period & \multicolumn{2}{l|}{ Apposition } & \multicolumn{2}{l|}{ Contrast } & \multicolumn{2}{l|}{ List/Sum. } & \multicolumn{2}{l|}{ Result/Inf. } & \multicolumn{2}{l|}{ Transition } & Total \\
\hline & $\#$ & $\begin{array}{l}\text { Norm. } \\
\text { freq. }\end{array}$ & $\#$ & $\begin{array}{l}\text { Norm. } \\
\text { freq. }\end{array}$ & $\#$ & $\begin{array}{l}\text { Norm. } \\
\text { freq. }\end{array}$ & $\#$ & $\begin{array}{l}\text { Norm. } \\
\text { freq. }\end{array}$ & $\#$ & $\begin{array}{l}\text { Norm. } \\
\text { freq. }\end{array}$ & \\
\hline 1 & 7 & 0.18 & 56 & 1.47 & 6 & 0.16 & 108 & 2.84 & 3 & 0.08 & 180 \\
\hline 3 & 27 & 0.88 & 67 & 2.19 & 36 & 1.18 & 88 & 2.88 & 10 & 0.33 & 228 \\
\hline Total & 34 & 0.50 & 123 & 1.79 & 42 & 0.61 & 196 & 2.86 & 13 & 0.19 & 408 \\
\hline
\end{tabular}


Peter J. Grund and Erik Smitterberg. 2014 "Conjuncts in Nineteenth-Century English: Diachronic Development and Genre Diversity." English Language and Linguistics 18(1): 157-181. (Accepted manuscript version; post-peer review)

Although the period differences in raw frequencies are statistically significant, ${ }^{14}$ table 6 shows that the increase in conjunct frequency in Science is not due to one or a few semantic types; rather, all types except Result/Inference display clear increases in frequency over time. However, as mentioned above, the high frequency of Result/Inference conjuncts in period 1 is mainly due to one single text; the apparent stability in the frequency of this type may thus be an effect of the sampling. Overall, the results for Science indicate that marking relationships between stretches of text became more important in general in academic writing during the nineteenth century, and our results are clear signs of large-scale genre development in this respect.

\section{SUMMARY AND CONCLUSIONS}

Our study of conjuncts in nineteenth-century English has shown that significant changes took place over the course of the century. Our results support Lenker's (2010) claim that Late Modern English is a crucial period in the development of the conjunctive system, and they add further insights into the details of this development. We point to increasing genre differentiation over the century. While Trials evidences relative stability, the frequency declines in Debates, Drama, Fiction, and Letters, and increases in History and Science. Most striking among these changes is the development in Science: the frequency of conjuncts per 1,000 words, 7.45 , is almost double that of the closest genre, Letters (3.73), by the end of the century, and the change is visible in nearly all semantic categories of conjuncts in Science. Our results thus suggest that the characteristic use of conjuncts in scientific and academic writing that has been attested in studies of

\footnotetext{
${ }^{14}$ d.f. $=4 ; \chi^{2}=34.8 ; \mathrm{p}<0.001$
} 
Peter J. Grund and Erik Smitterberg. 2014 "Conjuncts in Nineteenth-Century English: Diachronic Development and Genre Diversity." English Language and Linguistics 18(1): 157-181. (Accepted manuscript version; post-peer review)

twentieth-century English (Greenbaum 1969; Biber et al. 1999) began in the 1800s. This finding also underlines the importance of considering formal, learned genres when charting language change, as they can be in the forefront of the formation of new linguistic patterns, especially in terms of written language (Biber \& Gray 2011). At the same time, our study did not find evidence of frequent use of conjuncts in conversation, which has also been recorded in the twentieth century. This discrepancy may be due to differences in genre characteristics between genuine conversation and the speechrelated genres in CONCE.

Behind these general trends are also more fine-grained patterns in semantic categories, in individual conjuncts, and, to some extent, in stylistic preferences by individual authors. The different genres exhibit distinct profiles in terms of semantic categories of conjuncts. These profiles are clearly often tied in with the communicative purposes of the text categories. The relatively high percentages of Apposition, List/Summary, and Result/Inference in Science are probably a reflection of the importance of argumentation, exemplification, and drawing conclusions in this genre.

On the other hand, the predominance of Transition conjuncts in Drama and Trials points to the importance of highlighting shifts of topic in these dialogic genres. In terms of individual conjuncts, CONCE revealed a split between a set of six highly frequent items (however, then, so, therefore, yet, and now) and a larger group of less common conjuncts. While some conjuncts in the former category exhibit clear connections with a particular genre (e.g. now in Trials), the use of others was characteristic of groups of genres, such as so in informal, non-narrative genres, which again suggested that patterns evident in Present-Day English were also present in nineteenth-century English. 
Peter J. Grund and Erik Smitterberg. 2014 "Conjuncts in Nineteenth-Century English: Diachronic Development and Genre Diversity." English Language and Linguistics 18(1): 157-181. (Accepted manuscript version; post-peer review)

Many aspects of the usage of conjuncts in the nineteenth century remain to be explored, such as the variable sentential position of conjuncts and the relationship between conjunctive and non-conjunctive functions of multi-functional items such as then (see section 3.2.2; cf. Hasselgård 2010: 302-3). We will return to these issues in our future research. The results of the present study clearly indicate that conjuncts constitute an important area of Late Modern English syntax, which remains understudied despite a recent upsurge in scholarly interest.

\section{Appendix 1}

The list below includes all forms that were searched for using the Concordancer program in the WordSmith Tools software suite. The forms that actually occurred as conjuncts in the material are given in italics in the list. As regards the items here and indeed, 100 randomly selected instances of each form were examined, but when this search did not yield any conjunctive instances, they were not included in the full searches. Note that the forms are given with what is assumed to be the most frequent present-day spelling, which is intended to subsume spelling variants; for instance, anyway actually occurs in the corpus only with the spelling any way.

1), 1., i), i., I), I., 2., II., 3., III., 4., IV., 5., V., 6., VI., VII., VIII., IX., X., XI.

A.), A., a), a., above all, accordingly, admittedly, after all, again, alias, all in all, all the same, also, alternatively, altogether, anyhow, anyway, anyways, as a consequence, as a result, at all events, at any rate, at (the) last, at least, at the same time 
Peter J. Grund and Erik Smitterberg. 2014 "Conjuncts in Nineteenth-Century English: Diachronic Development and Genre Diversity." English Language and Linguistics 18(1): 157-181. (Accepted manuscript version; post-peer review)

besides, better, by comparison, by contrast, by the bye, by the same token, by the way, by way of comparison, by way of contrast consequently, contrarily, contrariwise, conversely, correspondingly e.g., else, equally finally, first (of all), firstly, for a start, for all that, for another (thing), for example, for instance, for one (thing), fourthly, further, furthermore

hence, here, however

i.e., in addition, in all (events), in any case, in any event, in comparison, in conclusion, in consequence, in contrast, in fine, in other words, in particular, in spite of it all, in spite of that, in sum, in that case, in the first instance, in the first place, in the meantime, in the meanwhile, in the same way, in the second place, in the third place, incidentally, indeed, instead last (of all), lastly, likeways, likewise meantime, meanwhile, more (than this), more accurately, more precisely, moreover namely, nevertheless, next, nonetheless, notwithstanding, now of course, on the contrary, on the one hand, on the other hand, on the other side, on top of it all, one, only, oppositely, otherways, otherwise, over and above, overall parenthetically, plus rather, right second, second of all, secondly, similarly, so, somehow, specifically, still, still and all that is (to say), that said, then, therefore, third, thirdly, though, thus, to begin with, to cap it (all), to conclude, to start with, to sum up, to summarize, to top it (all), too viz. 
Peter J. Grund and Erik Smitterberg. 2014 "Conjuncts in Nineteenth-Century English: Diachronic Development and Genre Diversity." English Language and Linguistics 18(1): 157-181. (Accepted manuscript version; post-peer review)

what is more, what is more important, whence, wherefore, which is to say, why then, worse, worse than all this

yet 
Peter J. Grund and Erik Smitterberg. 2014 "Conjuncts in Nineteenth-Century English: Diachronic Development and Genre Diversity." English Language and Linguistics 18(1): 157-181. (Accepted manuscript version; post-peer review)

Authors' addresses:

Dr. Peter J. Grund

Department of English

Wescoe Hall Rm. 3001

University of Kansas

1445 Jayhawk Blvd.

Lawrence, KS 66045

$U S A$

Email:pjgrund@ku.edu

Dr. Erik Smitterberg

Department of English

Uppsala University

P.O. Box 527

SE-75120 UPPSALA

Sweden

Email:erik.smitterberg@engelska.uu.se 
Peter J. Grund and Erik Smitterberg. 2014 "Conjuncts in Nineteenth-Century English: Diachronic Development and Genre Diversity.” English Language and Linguistics 18(1): 157-181. (Accepted manuscript version; post-peer review)

\section{REFERENCES}

Aijmer, Karin. 2002. English discourse particles: Evidence from a corpus. Amsterdam: John Benjamins.

Altenberg, Bengt. 1984. Causal linking in spoken and written English. Studia Linguistica 38(1), 20-69.

Altenberg, Bengt. 1986. Contrastive linking in spoken and written English. In Tottie \& Bäcklund (eds.), 13-40.

Altenberg, Bengt. 1999. Adverbial connectors in English and Swedish: Semantic and lexical correspondences. In Hasselgård \& Oksefjell (eds.), 249-68.

Barth-Weingarten, Dagmar \& Elizabeth Couper-Kuhlen. 2002. On the development of final though: A case of grammaticalization? In Wischer \& Diewald (eds.), 34561.

Bell, David M. 2004. Correlative and non-correlative 'on the other hand'. Journal of Pragmatics 36(12), 2179-84.

Bell, David M. 2010. Nevertheless, still and yet: Concessive cancellative discourse markers. Journal of Pragmatics 42(7), 1912-27.

Biber, Douglas. 1988. Variation across speech and writing. Cambridge: Cambridge University Press.

Biber, Douglas \& Edward Finegan. 1997. Diachronic relations among speech-based and written registers in English. In Nevalainen \& Kahlas-Tarkka (eds.), 253-75.

Biber, Douglas \& Bethany Gray. 2010. Challenging stereotypes about academic writing: Complexity, elaboration, explicitness. Journal of English for Academic Purposes 9, 2-20. 
Peter J. Grund and Erik Smitterberg. 2014 "Conjuncts in Nineteenth-Century English: Diachronic Development and Genre Diversity." English Language and Linguistics 18(1): 157-181. (Accepted manuscript version; post-peer review)

Biber, Douglas \& Bethany Gray. 2011. Grammatical change in the noun phrase: The influence of written language use. English Language and Linguistics 15(2), $223-50$.

Biber, Douglas, Stig Johansson, Geoffrey Leech, Susan Conrad \& Edward Finegan. 1999. Longman grammar of spoken and written English. Harlow: Pearson.

Borkin, Ann. 1979. Antithetic conjuncts in written English. RELC Journal 10(2), 4456.

Borkin, Ann. 1980. On some conjuncts signalling dissonance in written expository English. Studia Anglica Posnaniensia 12, 47-59.

Brinton, Laurel J. 1996. Pragmatic markers in English: Grammaticalization and discourse functions. Berlin: Mouton de Gruyter.

Charles, Maggie, Diane Pecorari \& Susan Hunston (eds.). 2009. Academic writing: At the interface of corpus and discourse. London: Continuum.

Defour, Tine. 2008. 'And so now...': The grammaticalisation and (inter)subjectification of now. In Nevalainen et al. (eds.), 17-36.

Denison, David \& Marianne Hundt. 2013. Defining relatives. Journal of English Linguistics 41(2), 135-67.

Dorgeloh, Heidrun. 2004. Conjunction in sentence and discourse: Sentence-initial and and discourse structure. Journal of Pragmatics 36, 1761-79.

Finell, Anne. 1992. The repertoire of topic changers in personal, intimate letters: A diachronic study of Osborne and Woolf. In Rissanen et al. (eds.), 720-35.

Fraser, Bruce 1999. What are discourse markers? Journal of Pragmatics 31(7), 931- 52. 
Peter J. Grund and Erik Smitterberg. 2014 "Conjuncts in Nineteenth-Century English: Diachronic Development and Genre Diversity." English Language and Linguistics 18(1): 157-181. (Accepted manuscript version; post-peer review)

Gardezi, S. Amina \& Hilary Nesi. 2009. Variation in the writing of economics students in Britain and Pakistan: The case of conjunctive ties. In Charles et al. (eds.), $236-50$.

Geisler, Christer. 2002. Investigating register variation in nineteenth-century English: A multi-dimensional comparison. In Reppen et al. (eds.), 249-71.

Greenbaum, Sidney. 1969. Studies in English adverbial usage. Coral Gables, FL: University of Miami Press.

Gustafsson, Larisa Oldireva. 2006. The passive in nineteenth-century scientific writing. In Kytö et al. (eds.), 110-35.

Halliday, M. A. K. 1994. An introduction to functional grammar, 2nd edn. London: Edward Arnold.

Halliday, M. A. K. \& Ruqaiya Hasan. 1976. Cohesion in English. London: Longman. Haselow, Alexander. 2011. Discourse marker and modal particle: The functions of utterance-final then in spoken English. Journal of Pragmatics 43(14), 3603-23.

Haselow, Alexander. 2012. Discourse organization and the rise of final then in the history of English. In Hegedüs \& Fodor (eds.), 153-75.

Hasselgård, Hilde. 2010. Adjunct adverbials in English. Cambridge: Cambridge University Press.

Hasselgård, Hilde \& Signe Oksefjell (eds.). 1999. Out of corpora: Studies in honour of Stig Johansson. Amsterdam: Rodopi.

Hegedűs, Irén \& Alexandra Fodor (eds.). 2012. English historical linguistics 2010: Selected papers from the sixteenth International Conference on English Historical Linguistics (ICEHL 16), Pécs, 23-27 August 2010. Amsterdam: John Benjamins. 
Peter J. Grund and Erik Smitterberg. 2014 "Conjuncts in Nineteenth-Century English: Diachronic Development and Genre Diversity." English Language and Linguistics 18(1): 157-181. (Accepted manuscript version; post-peer review)

Hickey, Raymond (ed.). 2010. Eighteenth-century English: Ideology and change.

Cambridge: Cambridge University Press.

Huddleston, Rodney \& Geoffrey K. Pullum. 2002. The Cambridge grammar of the English language. Cambridge: Cambridge University Press.

Hyland, Ken. 2005. Metadiscourse: Exploring interaction in writing. London: Continuum.

Jucker, Andreas H. \& Yael Ziv. 1998. Discourse markers: Introduction. In Jucker \& Ziv (eds.), 1-12.

Jucker, Andreas H. \& Yael Ziv (eds.). 1998. Discourse markers: Descriptions and theory. Amsterdam: John Benjamins.

Kytö, Merja, Juhani Rudanko \& Erik Smitterberg. 2000. Building a bridge between the present and the past: A corpus of 19th-century English. ICAME Journal 24, 8597.

Kytö, Merja, Mats Rydén \& Erik Smitterberg (eds.). 2006. Nineteenth-century English: Stability and change. Cambridge: Cambridge University Press.

Lenk, Uta. 1998. Marking discourse coherence: Functions of discourse markers in spoken English. Tübingen: Narr.

Lenker, Ursula. 2010. Argument and rhetoric: Adverbial connectors in the history of English. Berlin: Mouton de Gruyter.

Lenker, Ursula. 2011. A focus on adverbial connectors: Connecting, partitioning and focusing attention in the history of English. In Meurman-Solin \& Lenker (eds.), np.

Lindquist, Hans. 1989. English adverbials in translation: A corpus study of Swedish renderings. Lund: Lund University Press. 
Peter J. Grund and Erik Smitterberg. 2014 "Conjuncts in Nineteenth-Century English: Diachronic Development and Genre Diversity." English Language and Linguistics 18(1): 157-181. (Accepted manuscript version; post-peer review)

Lindquist, Hans \& Christian Mair (eds.). 2004. Corpus approaches to grammaticalization in English. Amsterdam: John Benjamins.

Mair, Christian \& Marianne Hundt (eds.). 2000. Corpus linguistics and linguistic theory: Papers from the twentieth International Conference on English Language Research on Computerized Corpora (ICAME 20). Freiburg im Breisgau 1999. Amsterdam: Rodopi.

Markus, Manfred. 2000. Wherefore therefore: Causal connectives in Middle English prose as opposed to Present-Day English. In Mair \& Hundt (eds.), 215-32.

Markus, Manfred, Yoko Iyeiri, Reinhard Heuberger \& Emil Chamson (eds.). 2012. Middle and Modern English corpus linguistics: A multi-dimensional approach. Amsterdam: John Benjamins.

Meurman-Solin, Anneli. 2011. Utterance-initial connective elements in early Scottish epistolary prose. In Meurman-Solin \& Lenker (eds.), np. http://www.helsinki.fi/varieng/journal/volumes/08/meurman-solin/

Meurman-Solin, Anneli \& Ursula Lenker (eds.). 2011. Connectives in synchrony and diachrony in European languages. Helsinki: University of Helsinki. http://www.helsinki.fi/varieng/journal/volumes/08/index.html

Mittwoch, Anita, Rodney Huddleston \& Peter Collins. 2002. Chapter 8. The clause: Adjuncts. In Huddleston and Pullum, 663-784.

Morrow, Phillip R. 1989. Conjunct use in business news stories and academic journal articles: A comparative study. English for Specific Purposes 8, 239-54.

Nevalainen, Terttu \& Leena Kahlas-Tarkka (eds.). 1997. To explain the present: Studies in the changing English language in honour of Matti Rissanen. Helsinki: Société Néophilologique. 
Peter J. Grund and Erik Smitterberg. 2014 "Conjuncts in Nineteenth-Century English: Diachronic Development and Genre Diversity." English Language and Linguistics 18(1): 157-181. (Accepted manuscript version; post-peer review)

Nevalainen, Terttu, Irma Taavitsainen, Päivi Pahta \& Minna Korhonen (eds.). 2008. The dynamics of linguistic variation: Corpus evidence on English past and present. Amsterdam: John Benjamins.

Peters, Pam, Peter Collins \& Adam Smith (eds.). 2009. Comparative studies in Australian and New Zealand English: Grammar and beyond. Amsterdam: John Benjamins.

Peterson, Peter G. 2009. Commas and connective adverbs. In Peters et al. (eds.), 27792.

Quirk, Randolph, Sidney Greenbaum, Geoffrey Leech \& Jan Svartvik. 1985. A comprehensive grammar of the English language. London: Longman.

Reppen, Randi, Susan M. Fitzmaurice \& Douglas Biber (eds.). 2002. Using corpora to explore linguistic variation. Amsterdam: John Benjamins.

Rissanen, Matti. 2004. Grammaticalisation from side to side: On the development of beside(s). In Lindquist \& Mair (eds.), 151-70.

Rissanen, Matti, Ossi Ihalainen, Terttu Nevalainen \& Irma Taavitsainen (eds.). 1992. History of Englishes: New methods and interpretations in historical linguistics. Berlin: Mouton de Gruyter.

Schiffrin, Deborah. 1987. Discourse markers. Cambridge: Cambridge University Press. Shaw, Philip. 2009. Linking adverbials in student and professional writing in literary studies: What makes writing mature. In Charles et al. (eds.), 215-35.

Smitterberg, Erik. 2005. The progressive in 19th-century English: A process of integration. Amsterdam: Rodopi.

Smitterberg, Erik. 2012. Colloquialization and NOT-contraction in nineteenth-century English. In Markus et al. (eds.), 191-206. 
Peter J. Grund and Erik Smitterberg. 2014 "Conjuncts in Nineteenth-Century English: Diachronic Development and Genre Diversity." English Language and Linguistics 18(1): 157-181. (Accepted manuscript version; post-peer review)

Tieken-Boon van Ostade, Ingrid \& Wim van der Wurff (eds.). 2009. Current issues in Late Modern English. Bern: Peter Lang.

Tottie, Gunnel \& Ingegerd Bäcklund (eds.). 1986. English in speech and writing. A symposium. Uppsala: Acta Universitatis Upsaliensis.

Ungerer, Friedrich. 1988. Syntax der englischen Adverbialen. Tübingen: Max Niemeyer.

Vandepitte, Sonia. 1993. A pragmatic study of the expression and the interpretation of causality: Conjuncts and conjunctions in modern spoken British English. Brussels: Paleis der Academiën.

Warner, Richard G. 1985. Discourse connectives in English. New York: Garland Publishing.

Williams, Howard A. 1996. An analysis of English conjunctive adverbial expressions. Unpublished Ph. D. Dissertation, UCLA.

Wischer, Ilse \& Gabriele Diewald (eds.). 2002. New reflections on grammaticalization. Amsterdam: John Benjamins.

Yeung, Lorrita. 2009. Use and misuse of 'besides': A corpus study comparing native speakers' and learners' English. System 37(2), 330-42. 